\title{
MEMBRAN KITOSAN TERMODIFIKASI TRIPOLIFOSFAT-HEPARIN DAN APLIKASINYA PADA PERMEASI UREA DAN KREATININ
}

\author{
Retno Ariadi Lusiana, Wahyu Putri Pranotoningtyas \\ Laboratorium Kimia Analitik, Departemen Kimia, FSM, Universitas Diponegoro, Semarang \\ retno.lusiana@live.undip.ac.id
}

\begin{tabular}{|l|}
\hline Artikel Info \\
$\begin{array}{l}\text { Diterima } \\
\text { tanggal } \\
20.01 .2018 \\
\text { Disetujui } \\
\text { publikasi } \\
\text { tanggal } \\
\text { 30.04.2018 } \\
\text { Kata kunci : } \\
\text { chitosan, } \\
\text { modification, } \\
\text { membranes, } \\
\text { permeative, } \\
\text { tensile strength. }\end{array}$ \\
\hline
\end{tabular}

\begin{abstract}
ABSTRAK
Telah dilakukan penelitian mengenai pembuatan membran paduan dari kitosan taut silang tripolifosfat (TPP) tercangkok heparin dengan polivinil alkoholpoli etilen glikol (PVA-PEG) sebagai kandidat membran semipermiabel. Metode yang digunakan pada penelitian ini adalah metode inversi fasa. Membran yang dihasilkan dikarakterisasi secara kimia dan fisika meliputi: gugus fungsi, serapan air, kuat tarik, ketahanan $\mathrm{pH}$, ketebalan, biodegradabilitas. Sifat permeatif membran dipelajari melalui uji kemampuan permeasi membran terhadap urea dan kreatinin. Hasil karakterisasi menunjukkan bahwa substitusi secara kimiawi berhasil dilaksanakan pada gugus amina kitosan. Modifikasi taut silang, cangkok dan campuran yang dilakukan terhadap kitosan meningkatkan kekuatan mekanik, kemampuan serapan air dan kemampuan permeasi terhadap urea dan kreatinin. Persentase permeasi meningkat 2-3 x dari permeasi membran kitosan tanpa modifikasi.
\end{abstract}

\section{ABSTRACT}

A study of blend membrane making from heparin grafted chitosan-trypoly phosphate with polyvinyl alcohol-ethylene glycol (PVA-PEG) as a semipermeel membrane candidate has been conducted. Method of membrane making using phase inversion method. The resulting membranes are characterized chemically and physically include: functional groups, water uptake, tensile strength, $p H$ resistance, thickness, biodegradability. The membrane permeative properties were studied by testing the membrane permeation capacity of urea and creatinine. The characterization results show that the substitution is chemically successfully performed on the chitosan amine group. Modified crosslinks, grafts and mixtures carried out on chitosan increase mechanical strength, water absorption ability and permeation ability to urea and creatinine. Percentage of permeation increased 2-3 x from chitosan membrane permeation without modification.

\section{PENDAHULUAN}

Kitosan, merupakan polimer alam yang bersifat biodegradabel, selektif dan reaktif (Yang et al., 2011). Reaktivitas kitosan didapatkan dari gugus $-\mathrm{OH}$ dan $-\mathrm{NH}_{2}$ yang terdapat pada rantai backbone kitosan, gugus tersebut mudah dimodifikasi menggunakan gugus fungsi lain pada 
lingkungan yang sesuai. Kandungan $-\mathrm{NH}_{2}$ berulang pada rantai backbone, membuat kitosan dapat terlarut dalam suasana asam, selanjutnya melalui proses inversi fasa dapat dibuat menjadi film tipis membran. Inversi fasa merupakan proses perubahan fasa dari cairan ke fasa padatan pada kondisi terkendali.

Dengan sifat-sifat yang bagus tersebut, membuat kitosan mulai banyak digunakan dalam beberapa bidang, salah satunya teknologi membran, yang dimanfaatkan pada proses pemisahan. Namun pada penggunaannya, membran berbahan dasar kitosan pure mempunyai beberapa kelemahan seperti kurangnya gugus aktif dan kekuatan mekanik yang tidak terlalu baik.. Kedua hal tersebut membuat proses pemisahan menjadi kurang efektif. Untuk mengurangi kelemahan tersebut, dibutuhkan modifikasi pada kitosan, baik modifikasi struktur ataupun modifikasi permukaan membran (Kiswandono, 2016).

Lusiana (2014), mengemukakan tiga cara untuk memodifikasi membran yaitu melalui reaksi cangkok (grafting), taut silang (crosslinking) dan pemaduan (blending). Modifikasi melalui tiga metode tersebut diyakini dapat meningkatkan kekuatan membran kitosan melalui peningkatan jumlah gugus fungsi, pengurangan muatan negatif dan meningkatkan kekuatan mekanik membran.

Liu et al., (2004) melakukan reaksi taut silang kitosan dan tripolifosfat untuk menghilangkan asam humat, hasilnya bahwa reaksi taut silang menambah reaktivitas membran dan meningkatkan adsorbsi. Salehi dan Madaeni (2014), memodifikasi membran kitosan dengan pemaduan poli etilen glikol (PEG) dan poli vinil alkohol (PVA). Dari modifikasi tersebut didapat bahwa PVA menambah elastisitas dan PEG menambah porositas membran. Lusiana et al., (2016) melakukan taut silang kitosan menggunakan asam sitrat yang dipadukan dengan PVA. Dari penelitian tersebut didapatkan, bahwa strategi taut silang dan paduan dapat merubah orientasi muatan pada permukaan membran sehingga permeasi meningkat.

Dengan mempelajari hal-hal tersebut, maka dalam penelitian ini akan dibuat suatu membran dari modifikasi kitosan melalui reaksi taut silang dengan tripolifosfat dilanjutkan reaksi cangkok dengan heparin dan pemaduan dengan PVA-PEG. Taut silang dengan tripolifosfat dan cangkok heparin dimaksudkan untuk menambah sisi aktif membran kitosan (Liu et al., 2004). Tripolipospat memiliki gugus - O reaktif yang bermuatan parsial negatif untuk mengimbangi muatan positif dari kitosan. Heparin merupakan senyawa yang biasa ditambahkan untuk mengurangi penggumpalan darah merah, karena sifat ketidakterterimaan darah terhadap membran. 
Selain itu, heparin memiliki gugus $-\mathrm{SO}_{3}$ berulang pada setiap monomernya (Badr, et al., 2014). Gugus $-\mathrm{SO}_{3}$, dengan $-\mathrm{O}$ tidak berpasangan membuat gugus ini dapat berfungsi sebagai sisi aktif pada membran kitosan. Selanjutnya untuk meningkatkan kekuatan mekanik dan porositas membran kitosan dilakukan pemaduan menggunakan polimer sintetik yang inert dan non toksik seperti PVA dan PEG. Untuk menguji kekuatan penambahan sisi aktif oleh adanya modifikasi pada membran kitosan, maka dilakukan uji kemampuan membran pada permeasi urea dan kreatinin.

\section{METODE}

\section{Alat dan Bahan}

Alat-alat yang digunakan dalam penelitian ini yaitu Neraca analitik (Ohauss), Alat gelas standar penelitian (Herma, Pyrex), Oven (Sigmatic), Stirer (Biomega), pH meter (HACH E C20), Thickness meter (Mitutoyo), Spektrofotometer UV-Vis (LW Scientific), Tensile strenght analizer, Alat permeasi, FTIR (Nicole Avatar 360).

Bahan-bahan yang digunakan dalam penelitian ini yaitu Kitosan (BM 40.000, derajat asetilasi $87 \%$, Biotech Surindo), Asam asetat glasial 96,6\%, Natrium tripolifosfat p.a (Merck), PVA (Fisher Scientific, Canada), PEG (Merck), Heparin p.a, NaOH p.a (Merck), Asam pikrat p.a (Sigma Aldrich), $\mathrm{HCl}$ p.a (Merck), Akuades, $\mathrm{H}_{3} \mathrm{PO}_{4}$ (Merck), $\mathrm{Na}_{2} \mathrm{HPO}_{4}$ (Merck), Kreatinin (Merck), Urea (Merck).

\section{Metoda}

\section{Sintesis kitosan taut silang tripolifosfat (CS-TPP)}

Sebanyak $1,5 \mathrm{~g}$ kitosan dilarutkan dalam $90 \mathrm{ml}$ asam asetat $1 \%$. Selanjutnya ditambahkan $10 \mathrm{ml}$ larutan tripolifosfat $1,5 \%$ dan dipanaskan pada suhu $70-80{ }^{\circ} \mathrm{C}$ selama 4 jam dan disimpan sebagai larutan stok membran.

\section{Pembuatan membran}

Larutan CS-TPP hasil sintesis dan larutan campuran dengan PVA-PEG dituangkan dalam cawan petri dan dikeringkan dengan oven pada suhu $30-50{ }^{\circ} \mathrm{C}$ selama 24 jam. Setelah kering ditambakan larutan basa dan dicuci hingga netral. 


\section{Reaksi cangkok dengan heparin}

Membran CS-TPP/PVA-PEG dicangkok dengan heparin. Pencangkokan dilakukan dengan perendaman membran pada heparin $100 \mathrm{IU}$ pada katalis asam selama 2 jam.

\section{Karakterisasi Membran}

Karakterisasi pada membran meliputi gugus fungsi (FTIR), kekuatan mekanik dan regangan (tensile strenght analizer), uji serapan air.

\section{Aplikasi permeasi membran terhadap kreatinin dan urea}

Uji permeasi terhadap kreatinin dan urea dilakukan dengan alat permeasi yang terdiri dari dua chamber yaitu chamber sumber dan chamber akseptor yang di tengahnya terdapat membran. Fasa sumber berisi kreatinin $15 \mathrm{ppm}$ dan urea $500 \mathrm{ppm}$ yang dibuat dengan buffer fosfat dan fasa akseptor berisi buffer fosfat. Permeasi dilakukan selama 6 jam dengan pengambilan sampel akseptor setiap jamnya dan pengompleks kreatinin menggunakan asam pikrat, diukur menggunakan spektrofotometer UV-Vis pada panjang gelombang $486 \mathrm{~nm}$ dan 4-dimetilamin benzaldehida sebagai pengompleks urea diukur pada panjang gelombang $430 \mathrm{~nm}$.

\section{HASIL DAN PEMBAHASAN}

\section{Sintesis CS-TPP}

Gambaran mekanisme reaksi taut silang kitosan dengan tripolifosfat dapat dijelaskan melalui dua tahap reaksi, seperti terlihat pada Gambar 1. Reaksi taut silang dilakukan dalam suasana asam yang memungkinkan terjadinya transfer proton menuju molekul kitosan yang menyebabkan terbentuknya muatan positif pada atom $\mathrm{N}$ pada gugus $-\mathrm{NH}_{2}$. Pada suasana asam hanya ada ion $-\mathrm{PO}_{4}$ dalam larutan natrium tripolifosfat, sedang pada suasana basa terdapat $\mathrm{OH}^{-}$ dan $-\mathrm{PO}_{4}$ bersama-sama dalam larutan yang menyebabkan persaingan antara kedua ion untuk berinteraksi dengan gugus $\mathrm{NH}_{3}{ }^{+}$. Untuk menghindari persaingan tersebut maka reaksi taut silang dilakukan pada suasana asam.

Karakterisasi kitosan tertaut silang tripolifosfat dilakukan dengan spektra IR yang dapat diamati pada Gambar 2. Spektra spesifik kitosan ditunjukkan oleh adanya serapan pada 3425 $\mathrm{cm}^{-1}$ yang menunjukkan regangan $\mathrm{O}-\mathrm{H}$ dari gugus $-\mathrm{OH}$ kitosan serta pada $2931 \mathrm{~cm}^{-1}$ yang menunjukkan adanya regangan $\mathrm{C}-\mathrm{H}$. Serapan pada 1597 dan $1658 \mathrm{~cm}^{-1}$ merupakan serapan kembar 
gugus N-H primer. Serapan pada bilangan gelombang $1071 \mathrm{~cm}^{-1}$ yang menunjukkan serapan khas gugus $\mathrm{C}-\mathrm{O}$ pada struktur sakarida kitosan.

Tahap 1. protonasi kitosan

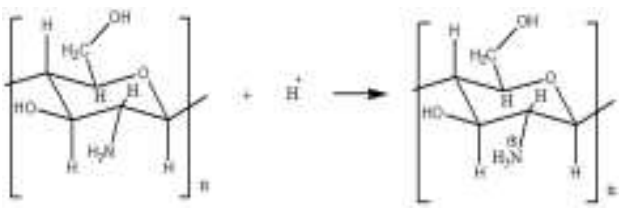

Tahap 2. Reaksi taut silang

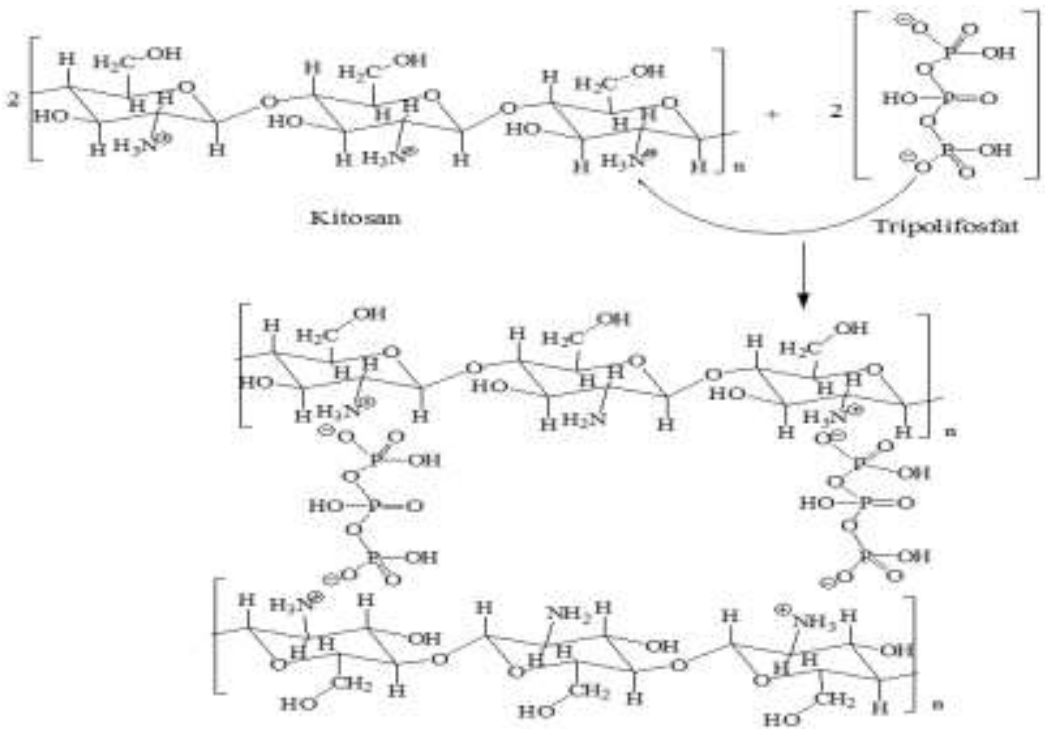

Gambar 1. Mekanisme reaksi taut silang kitosan dengan tripolipospat (Hsieh et al., 2008)

Spektra spesifik pada kitosan-tripolifosfat ditunjukkan dengan hilangnya serapan gugus kembar menjadi tunggal. Serapan juga bergeser dari 1597-1658 ke daerah $1500-1590 \mathrm{~cm}^{-1}$ menunjukkan deformasi gugus $\mathrm{N}-\mathrm{H}$ karena terjadinya proses taut silang. Pada CS-TPP terdapat serapan spesifik pada bilangan gelombang $3448 \mathrm{~cm}^{-1}$ menunjukkan pergeseran dari spektra kitosan dan spektra yang dihasilkan lebih melebar. Karakteristik ini menunjukkan serapan gugus O-H sehingga dapat diindikasikan bahwa sebagian besar gugus amina primer dari kitosan telah mengalami taut silang dengan tripolifosfat. Terjadinya pergeseran spektra tersebut 
mengindikasikan telah terjadi reaksi taut silang antara gugus $-\mathrm{NH}_{2}$ kitosan dengan tripolifosfat. Spektra lemah pada bilangan gelombang 1597 dan $1658 \mathrm{~cm}^{-1}$ pada spectra IR kitosan yang merupakan indikasi dari tekukan $\mathrm{N}-\mathrm{H}$ primer telah mengalami pergeseran menjadi $1589 \mathrm{~cm}^{-1}$ dan menjadi satu puncak saja. Hal ini menindikasikan bahwa gugus amina primer dari kitosan telah mengalami modifikasi. Hal ini mempertegas bahwa taut silang tripolifosfat terhadap gugus amina kitosan telah berhasil dilakukan. Hasil FTIR ini sesuai dengan hasil yang didapat oleh Gierzewska et al., 2016.

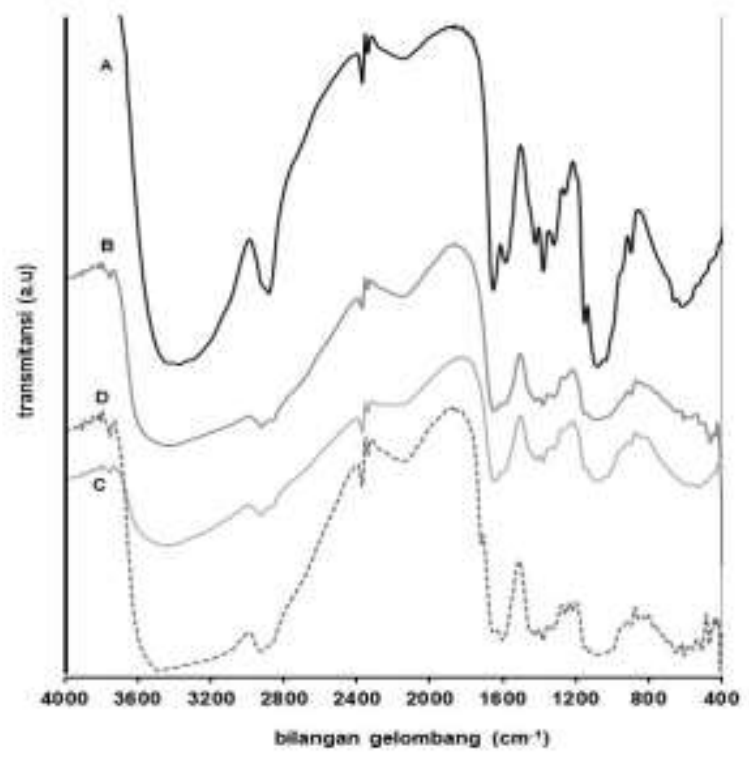

Gambar 2. Spektrum FTIR CS (A), CS-TPP (B), CS-TPP-PVA/PEG (C) dan CS-TPP-PVA/PEG-Hep (D)

\section{Membran CS-TPP/PVA-PEG}

Pemaduan PVA-PEG pada CS-TPP dilakukan untuk meningkatkan kekuatan mekanik dari membran kitosan. Sifat hidrofob yang dimiliki kitosan merupakan salah satu kekurangan jika dijadikan sebagai membran, karena akan menyebabkan terjadinya adsorbsi protein pada permukaan membran sehingga akan menghambat proses permeasi kreatinin maupun urea. Untuk meningkatkan hidrofilisitas membran kitosan perlu adanya pemaduan dengan material yang lebih hidrofilik. PVA digunakan sebagai polimer paduan kitosan karena kemampuannya dalam 
menyerap air yang tinggi. Selain PVA juga digunakan PEG, hal ini bertujuan untuk memperbaiki porositas membran.

Karakterisasi pemaduan PVA-PEG pada CS-TPP dilakukan dengan spektra IR yang dapat diamati pada Gambar 2. Adanya kenaikan intensitas serapan di sekitar $2884 \mathrm{~cm}^{-1}$ dan $1100 \mathrm{~cm}^{-1}$ menunjukkan gugus $\mathrm{CH}_{2}$ dan regangan gugus -C-O-C dari PEG. Spektra vibrasi $\mathrm{CH}$ simetris dari gugus CH-OH PVA ditunjukkan pada bilangan gelombang $1377 \mathrm{~cm}^{-1}$. Dan karakter dari ikatan C-O dapat dilihat pada bilangan gelombang $1415 \mathrm{~cm}^{-1}$. Hal ini sesuai dengan penelitian dari Hassani et al., 2015.

\section{Reaksi cangkok dengan Heparin}

Reaksi cangkok bertujuan untuk menambah sisi aktif membran kitosan dari sisi permukaan. Hal ini dimungkinkan karena pada reaksi taut silang tidak semua gugus $-\mathrm{NH}_{2}$ dan OH pada molekul kitosan dapat tertaut silang, dan heparin mampu melakukan reaksi cangkok dengan sisa gugus amina dan hidroksil pada permukaan membran.

Untuk melihat keberhasilan reaksi cangkok heparin perlu dilakukan karakterisasi gugus fungsi dengan spektrofotometer FTIR. Setelah reaksi cangkok terjadi perubahan spektra pada serapan 1597 dan $1651 \mathrm{~cm}^{-1}$ yang bergeser menjadi satu puncak saja. Hal ini menunjukkan bahwa terjadi ikatan pada gugus amina primer dengan heparin. Pada bilangan gelombang sekitar $902 \mathrm{~cm}^{-}$ ${ }^{1}$ muncul puncak yang merupakan gugus $-\mathrm{SO}_{3}$ dengan intensitas rendah. Ini dimungkinkan gugus $-\mathrm{SO}_{3}$ pada heparin sedikit yang tercangkok pada permukaan membran karena sebagian besar gugus aktif kitosan telah tertaut silang dengan natrium tripolipospat.

\section{Karakterisasi Membran}

\section{Uji kuat tarik membran}

Peningkatan kuat tarik/regang membran sejalan dengan peningkaan elongasi membran. Kedua besaran tersebut merupakan parameter penting untuk mengetahui kekuatan mekanik membran. Pemaduan dengan PVA-PEG meningkatkan kekuatan mekanik membran kitosan termodifkasi TPP menghasilkan membran yang lebih ulet dan fleksibel. Dengan meningkatnya fleksibilitas membran, akan meningkatkan kekuatan mekanik membran, sehingga membran tidak 
mudah rusah saat diaplikasikan dalam lingkungan berair selama waktu tertentu. Nilai fleksibiltas akan berkorelasi dengan sifat hidrofilisitas membran.

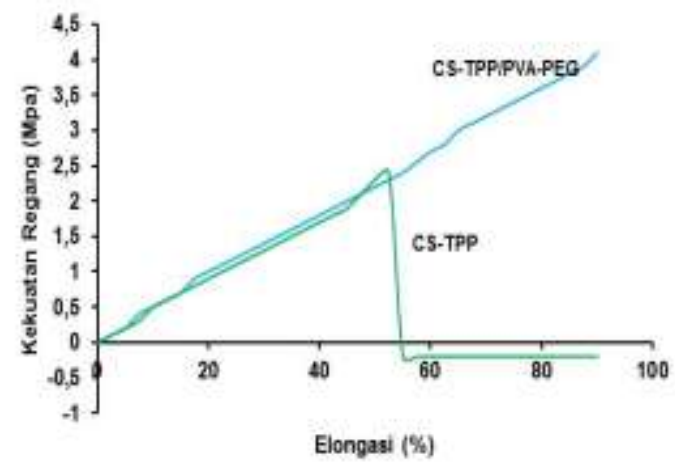

Gambar 3. Kuat tarik membran

\section{Uji Serapan Terhadap Air}

Uji serapan terhadap air semua membran dapat dilihat pada Gambar 4.

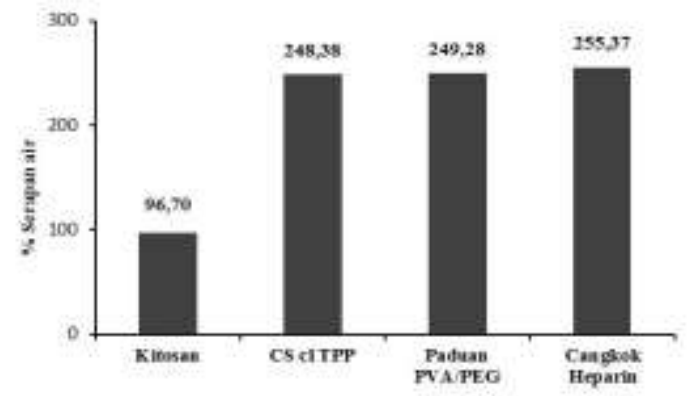

Gambar 4. Persentase Serapan Terhadap Air

Terdapat perbedaan persentase serapan terhadap air pada berbagai membran. Membran kitosan mempunyai nilai serapan air sebesar 96,7 \%, CS-TPP mempunyai serapan air 248,2\%. Paduan dengan PVA-PEG menaikkan sedikit serapan air menjadi 249,3\%, nilai serapan air tertinggi didapatkan ketika membran tercangkok heparin yaitu sebesar $255,4 \%$. Hal ini menunjukkan modifikasi kitosan dengan gugus fungsi dan campuran dengan polimer seperti PVA dapat meningkatkan hidrofilisitas membran. Hal ini sesuai dengan hasil dari uji kuat tarik, semakin hidrofil maka akan dihasilkan fleksibilitas yang semakin tinggi pula. 


\section{Permeasi Kreatinin}

Kreatinin merupakan salah satu senyawa toksin uremat dengan berat molekul $113 \mathrm{~g} / \mathrm{mol}$. Selain karena keberadaan pori membran, permeasi kreatinin juga terjadi akibat adanya gugus aktif yang ada pada membran. Permeasi dilakukan selama 6 jam dengan konsentrasi 15 ppm. Hasil permeasi kreatinin membran CS-TPP dapat dilihat Gambar 5.

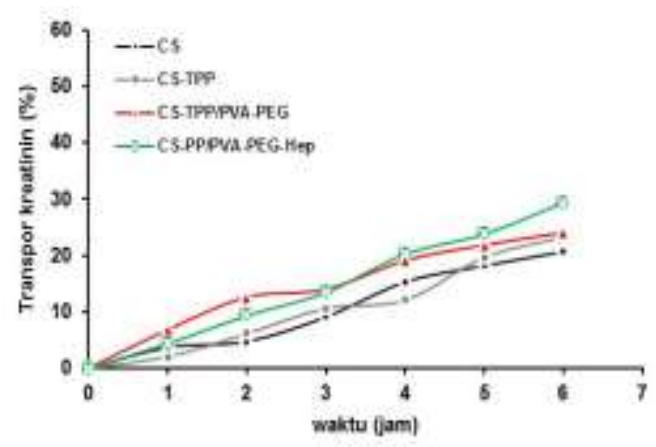

Gambar 5. Persentase permeasi kreatinin

Reaksi cangkok dengan heparin mampu menaikkan persentase permeasi hingga 29,33\%. Sedangkan persentase permeasi paling kecil adalah membran kitosan dengan persentase permeasi 20,66\%.Heparin memperbaiki membran dari sisi permukaan membran (surface area) dan reaksi taut silang NaTPP terjadi pada struktur material membran secara keseluruhan. Semakin banyak gugus aktif yang ditambahkan pada kitosan, maka persentase permeasi kreatinin akan semakin meningkat. Hal ini dibuktikan dari hasil permeasit pada membran kitosan murbi dengan kitosan termodifikasi.

\section{Permeasi Urea}

Urea memiliki berat molekul yang lebih kecil dari kreatinin yaitu $60 \mathrm{~g} / \mathrm{mol}$ sehingga persentase permeasi urea akan lebih tinggi dari persentase permeasi kreatinin. Permeasi urea dilakukan pada semua membran selama 24 jam dengan konsentrasi 500 ppm. Konsentrasi urea pada akseptor diukur setiap jamnya.

Hasil permeasi urea yang paling kecil pada membran kitosan murni. Urutan berikutnya adalah membran CS-TPP. Ini mengindikasi bahwa reaksi taut silang dengan gugus tripoli fosfat 
menaikkan jumlah sisi aktif sehingga akan berkorelasi dengan peningkatan persentase permeasi urea. Demikian juga dengan modifikasi menggunakan heparin yang juga menaikkan persentase permeasi dari membran kitosan. Dari data tersebut dapat dikatakan bahwa semakin banyak sisi aktif sebagai akibat proses modifikasi terhadap kitosan, maka meningkatkan kekuatan permeasi membran. Hal ini menunjukkan bahwa proses permeasi berjalan secara aktif. Dapat dilihat, bahwa semakin lama waktu permeasi maka persentase permeasi semakin tinggi.

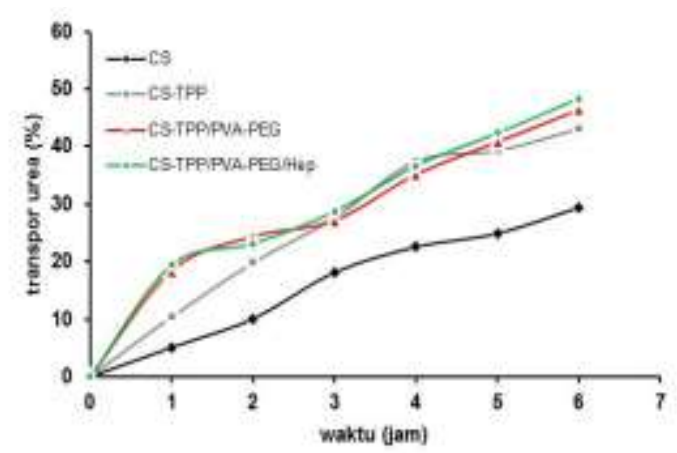

Gambar 6. Persentase permeasi urea

\section{KESIMPULAN}

Membran kitosan termodifikasi telah berhasil dibuat menggunakan metode inversi fasa. Selain meningkatkan kekuatan mekanik, reaksi modifikasi dengan gugus fungsi fosfat dan sulfat terhadap gugus kitosan dapat meningkatkan kemampuan permeasi membran terhadap kreatinin maupun urea melalui penambahan sisi aktif.

\section{UCAPAN TERIMAKASIH}

Terimakasih kepada FSM UNDIP yang telah memberi bantuan dana penelitian. 


\section{DAFTAR PUSTAKA}

Kiswandono, A.A., 2016, Membran Membrane Cair Untuk Pemisahan Fenol, Analit: Analytic \& Environment. Chem., 1,1, 78-91

Badr, I.H., Gouda, M., Abdel-Sattar, R., and Sayour, H.E., 2104, Reduction Of Thrombogenicity Of PVC-Based Sodium Selective Membrane Electrodes Using Heparin-Modified Chitosan, Carbohy. Polym, 99: 783-790

Hsieh, F.M., Huang, C., Lin, T. F., Chen, Y. M., dan Lin, J. C., 2008, Study Of Sodium Tripolyphosphate-Crosslinked Chitosan Beads Entrapped With Pseudomonas Putida For Phenol Degradation. Proc. Biochemi, 43(1), 83-92

Liu, C., Bai, R., dan Nan, L., 2004, Sodium Tripolyphosphate (TPP) Croslinked Chitosan Membranes and Application in Humic Acid Removal, AlChe Annual Meeting, Conference Proceedings, Chem \& Biomol

Lusiana, R.A., 2014, Sintesis Senyawa Turunan Kitosan melalui Reaksi Cangkok dan Taut Silang dan Aplikasinya sebagai Membran Biokompatibel Hemodialisis, Disertasi, Kimia, Universitas Gajah Mada

Lusiana, R.A., Siswanta, D., and Mudasir, 2016, Preparation of Citric Acid Crosslinked Chitosan/Poly(Vinyl Alcohol) Blend Membranes for Creatinine Permeasit. Indones. J. Chem, 16,2

Ma, L., Su, B, Cheng, C., Yin, Z., Qin, H., Zhao, J., Sun, S., and Zhao, C., 2014, Toward Highly Blood Compatible Hemodialysis Membranes Via Blending With Heparin-Mimicking Polyurethane; Study In Vitro And In Vivo, J. Membr. Sci, 470,90-101

Salehi, E., dan Madaeni,S.S., 2013, Influence Of PEG As Pore-Generator On Morphology And Performance Of Chitosan/PVA Membrane Adsorbent, Appl. Surf. Sci., 288, 537-541

Yang, S.J., Lin, F.H., Tsai, H.M., Lin, C.F., Chin, H.C., Wong, J.M., dan Shieh, M.J., 2011, Alginate-Folic Acid-Modified Chitosan Nanoparticles For Photodynamic Detection Of Intestinal Neoplasms, Biomaterials, 32, 2174-2182

Gierszewska, M., and Czubenko, J.O., 2016, Chitosan-Based Membranes With Different Ionic Crosslinking Density For Pharmaceuticsl And Industrial Application., Carbohydr. Polym., $153,501-511$

Hassani, S., Laouini, A., Fessi, H, and Charcoxet, C., 2015, Preparation Of Chitosan-TPP Nanoparticles Using Microengineered Membranes-Effect Of Paramaters And Encapsulation Of Tacrine, Colloids and Surfaces A: Physicochem. Eng. Aspect, 482, 34-43 